\title{
Ruiny zamków i grodzisk z obszaru Warmii biskupiej na mapie Kaspara Hennenbergera z 1576 r.
}

\section{Robert Klimek}

W 1576 r. ukazała się w Królewcu pierwsza szczegółowa jak na owe czasy mapa Prus Książęcych autorstwa Kaspara Hennenbergera Prussiae, das ist das Landes zu Preussen welche herrliste Theil ist Sarmathiae Europeae eigentliche und warhafftige Beschreibung. Odegrała ona wielką rolę w historii kartografii tego obszaru, albowiem aż do poł. XVIII w. stanowiła podstawę map Prus wydanych na zachodzie Europy. Jej autor, Kaspar Hennenberger ${ }^{1}$ (1529-1600), urodził się w Ehrlich w Turyngii, skąd we wczesnej młodości przybył do Prus. W latach 1550-1554 studiował teologię protestancką na uniwersytecie w Królewcu, a po jej ukończeniu pracował jako pastor, a następnie proboszcz parafii w Domnowie (Domnau), zaś od 1560 r. w Mühlhausen nad rzeką Bezledą w Natangii. Od 1590 r. Hennenberger był pastorem przy kościele szpitalnym na Lipniku (Löbechnicht), dzielnicy Królewca². Zmarł 29 lutego 1600 r. i został pochowany przy ołtarzu tamtejszego kościoła szpitalnego ${ }^{3}$.

Już jako student Hennenberger interesował się geografią i kartografią. Rok po ukończeniu studiów wykonał i wydał mapę Inflant, która niestety zaginęła i obecnie nie jest znana. W 1584 r., na podstawie źródeł pisanych,

\footnotetext{
1 W polskiej literaturze przedmiotu zazwyczaj spotykamy zapis nazwiska Henneberger. Jest to błąd, na który zwrócił już uwagę Tadeusz Oracki. T. Oracki, Stownik biograficzny Warmii, Prus Książęcych i Ziemi Malborskiej od połowy XV do końca XVIII wieku, t. 1: A-K, Olsztyn 1984, s. 93. Na uzasadnienie właściwego zapisu można przytoczyć najważniejszą publikację tego wybitnego kartografa - Erclerung der preussischen grossern Landtaffel oder Mappen, Königsberg 1595, na której podpisuje się jako Caspar Hennenberger.

2 J. Szeliga, Rozwój kartografii Wybrzeża Gdańskiego do roku 1772 Wrocław-Warszawa-Kraków-Gdańsk-Łódź 1982, s. 44. Według Tadeusza Orackiego studia na Uniwersytecie Królewieckim Hennenberger rozpoczął w 1550 r. W latach 1550-1560 byt diakonem w Domnowie, następnie w Młynarach (1560-1589). W 1589 r. otrzymał beneficjum przy szpitalu książęcym w Królewcu. Zob. T. Oracki, Stownik biograficzny, s. 93.

3 Caspar Hennenberger's Grosse Landtafel von Preussen in 9 Blättern
} (Erste Ausgabe vom Jahre 1576), Königsberg 1863. opracował historyczną mapę Prus Prussia Vetus Auctore Casp[ero] Hennebergero oraz geograficzno-historyczny opis Prus zatytułowany Kurze und warhafftige Beschreibung des Landes zu Preussen (1584). Najważniejszym i najbardziej znanym jego dziełem jest jednak mapa Prus wykonana w 1576 r. Hennenberger sporządził ją głównie na podstawie własnych pomiarów i materiałów zebranych w latach 1569-1576, w czasie siedmioletniej podróży po kraju $^{4}$. Podstawę mapy stanowiły miejscowości o znanych ówcześnie współrzędnych. Opracowaniem dobrej mapy Prus zainteresowany był książę Albrecht Fryderyk, który sfinansował prace kartografa. Działania Hennenbergera w terenie prawdopodobnie polegały na wyznaczaniu kierunków między ważniejszymi miejscowościami oraz innymi obiektami, jak i określaniu odległości na podstawie przebytej drogi. Kartograf sam przeniósł rysunek mapy na drewniane klocki, które następnie wyrytował Kaspar Felbinger. Odbitki zostały wykonane w drukarni w Królewcu. Mapa składa się z 9 arkuszy o łącznych wymiarach $103 \times 91 \mathrm{~cm}$. Obejmuje zaś obszar od $53^{\circ} 00^{\prime}$ do $55^{\circ} 50^{\prime}$ szerokości geograficznej $\mathrm{N}$ oraz od $44^{\circ} 20^{\prime}$ do $49^{\circ} 47^{\prime}$ długości E. Podczas wykreślania długości geograficznej Hennenberger - prawdopodobnie za Gerardem Mercatorem - położenie południka zerowego określił na wysokości Wysp Zielonego Przylądka. Powyższa mapa nie ma wykreślonej siatki kartograficznej, a jedynie na skrajnych ramach arkuszy zaznaczony jest jednominutowy podział. Na mapie Prus, podobnie jak na innych tworzonych ówcześnie, nie została ustalona skala liczbowa. Według Jana Szeligi, na podstawie dokonanych 40 pomiarów, skala mapy wynosi 1:368 000, przy czym w kierunku równoleżnikowym jest większa od

\footnotetext{
4 J. Szeliga, Rozwój kartografii, s. 45.
} 
średniej (1:35 000), a w kierunku południkowym - mniejsza $(1: 387000)^{5}$. O wartości tej mapy i zapotrzebowaniu na nią świadczą jej liczne wznowienia i przeróbki. Już w 1595 r. doczekała się drugiego wydania uzupełnionego o obszerny opis historyczny ${ }^{6}$. Kolejne edycje ukazywały się już w królewieckiej oficynie Segebadów w latach: 1627, 1629, 1638, 1639, 1655 i $1679^{7}$. Mimo wielu dziewiętnastowiecznych wydań mapa ta była rzadkim okazem, w związku z czym w 1863 r. wykonano w Królewcu jej fotolitograficzną reprodukcję w skali oryginału - Caspar Hennenberger's Grosse Landtafel von Preussen in 9 Blättern (Erste Ausgabe vom Jahre 1576) $)^{8}$. Oprócz wydań oryginalnych ukazało się wiele przeróbek tej mapy. Była ona bowiem podstawą do przedstawiania ziem pruskich przez prawie dwa wieki'. Jej treść jest bardzo bogata $\mathrm{w}$ porównaniu ze starszymi mapami Prus, np. Henryka Zella z 1542 r. ${ }^{10}$ Największą różnorodnością przedstawień cechuje się obraz sieci osadniczej. Autor wyodrębnił w niej cztery rodzaje miast (stolica, miasto ufortyfikowane, miasto ufortyfikowane z zamkiem, miasto otwarte) i trzy rodzaje wsi (parafialna, jarmarczna i pozostałe). Poza tym znalazły się tu dwory szlacheckie, dwory myśliwskie, zamki i klasztory. Bogata jest również sieć hydrograficzna, przede wszystkim jeziora i rzeki. Przedstawione zostały również lasy, większe bagna, ukształtowanie terenu, a także pola bitew,

\footnotetext{
5 Tamże, s. 45-46. Skala mapy jest podawana różnie i nie została ostatecznie ustalona w literaturze przedmiotu, np. w opisie tejże mapy Kaspara Hennenbergera z 1863 r. jest 1:400 000. Caspar Hennenberger's Grosse Landtafel von Preussen. Ostatnio Jan Szeliga podawat, że skala wynosi 1:380 000, zaś Stanisław Alexandrowicz twierdzi, że 1:370 000. J. Szeliga, Działalność kartograficzna Samuela i Jana Władystawa Suchodolców w Prusach w XVII i XVIII wieku, Warszawa 2004, s. 24; S. Alexandrowicz, Kartografia Wielkiego Księstwa Litewskiego od XV do połowy XVIII wieku, Warszawa 2012, s. 99-100.

$6 \mathrm{C}$. Hennenberger, Erclerung der preussischen grossern Landtaffel oder Mappen, Königsberg 1595.

7 P. Grabowski, Obraz terytorium Prus Wschodnich w kartografii XV-XIX wieku, w: Ziemie dawnych Prus Wschodnich w kartografii, red. P. Grabowski, J. Ostrowski, Olsztyn 1997, s. 22.

8 Zob. przyp. 3. Do wykonania kopii fotolitograficznej posłużyła mapa z 1629 r. (wyd. 4).

9 Z mapy Hennenbergera korzystali m.in.: Abraham Ortelius (15271598) - mapa Prussiae vera descriptio, Antwerpia 1584; Gerard Mercator (1512-1594) - mapa Prussia zamieszczona w Atlas sive cosmographicae, Duisburg 1595; Matthäus Merian (1593-1650) -
}

hamernie żelaza i ważniejsze mosty ${ }^{11}$. Bardzo ważne są na tej mapie dwa inne aspekty ikonograficzne. Pierwszy z nich dotyczy oznaczenia miast, które łudząco przypominają ich widok w poł. XVI w. Wyraźnie widać charakterystyczny kształt zamków, kościołów, katedr i fortyfikacji miejskich. Na obszarze Warmii biskupiej bardzo wyraźnie zaobserwować można miniaturę wzgórza katedralnego we Fromborku, zamku w Lidzbarku Warmińskim, kościoła w Braniewie czy kolegiaty w Dobrym Mieście. Miniaturowe wizerunki miast na mapie Hennenbergera są bardzo podobne do rycin przedstawionych $\mathrm{w}$ publikacji Christopha Hartknocha ${ }^{12}$. Na podstawie własnych obserwacji wysuwam tezę, że symbole graficzne, które na mapie przedstawiały wiejskie kościoły, również były odzwierciedleniem ich ówczesnego wyglądu. Prawdopodobnie nie bez znaczenia był fakt, że autor mapy przez siedem lat uczestniczył w podróży przygotowawczej po Prusach, podczas której oprócz pomiarów kartograficznych robił także zapewne szkice charakterystycznych budowli. Drugim bardzo ważnym i niestety często pomijanym w literaturze przedmiotu symbolem ikonograficznym na mapach Hennenbergera są kopczyki z krzyżem, opisane w legendzie mapy jako „Ein Berg da vor alters ein Schloss drauf gewesen" - czyli wzgórze, na którym dawniej znajdował się zamek (grodzisko) ${ }^{13}$.

mapa Prussiae Nova Tabula, 1652; Johannes Janssonius (1588-1664) - Prussia accurate descripta a Gasparo Henneberg Erlichensi, mapa wydawana w latach 1647-1658 w Amsterdamie; Nicolaus Visscher I (1618-1689), Nicolaus Visscher II (1649-1702) - Tabula Prussiae Eximia, mapa wydawana do końca XVII w.; Peter Schenk (1660-1718) - Regni Prussici Accuratissima Delineatio, Amsterdam [ok. 1713]; Johann Baptist Homman (1664-1724), Regnum Borussiae, Norimbergae 1710; Mathäus Seutter (1678-1757), Borussia Regnum, Augsburg 1720; Gilles Robert de Vaugondy (1688-1766), La Prusse divisée en Prusse Royale, et Prusse Ducale, Paris 1751.

10 Zmniejszona kopia mapy zamieszczona została w: J. Szeliga, Rozwój kartografii, s. 40-41.

11 J. Szeliga, Działalność kartograficzna, s. 24.

12 Ch. Hartknoch, Alt- und neues Preussen, oder preussischer Historien zwei Theile, Frankfurt-Leipzig 1684

13 Takie oznaczenia z opisem Mons arcis vastata pojawiały się także na niektórych wzorowanych na Hennenbergerze nowożytnych mapach Prus wydawanych przez XVI i XVII-wiecznych zachodnioeuropejskich kartografów: Abrahama Orteliusa, Matthäusa Meriana, Johannesa Janssoniusa, Nicolausa Visschera, Petera Schenka oraz na rękopiśmiennych 
Tematyka średniowiecznych założeń obronnych na mapach nowożytnych Prus częściowo została poruszona przez Hansa Cromego w odniesieniu do mapy Hennenbergera z 1584 r. $^{14}$ oraz Jerzego Antoniewicza, ale relikty założeń obronnych $\mathrm{w}$ pobliżu następujących miejscowości: Łuknajno, Tuchlin, Okartowo, Tyrkło, Nowe Guty, Kwik oraz Zdory. Obiekt w Okartowie był ruiną zamku krzyżackiego, ostatecznie zniszczonego przez

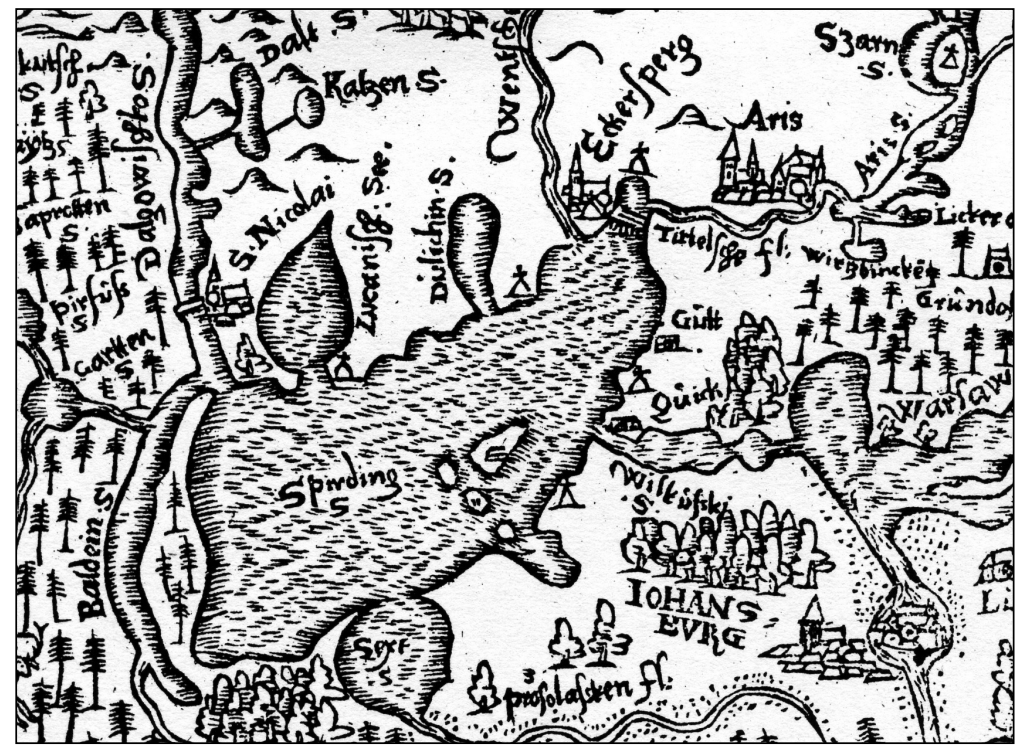

Ryc. 1. Fragment mapy Kaspara Hennenbergera "Prussiae, das ist das Landes zu Preusse” z 1576 r. - okolica jeziora Śniardwy z zaznaczonymi sygnaturami

dotyczyła ona części map Józefa Narońskiego z poł. XVII w. ${ }^{15} \mathrm{Na}$ mapie Prussiae, das ist das Landes zu Preussen Hennenberger naniósł 55 sygnatur oznaczających tego typu obiekty. Najwięcej, bo aż 6 umiejscowił w okolicy jeziora Śniardwy oraz $5 \mathrm{w}$ pobliżu Insterburga. Nad Śniardwami Hennenberger zaznaczył

mapach Józefa Narońskiego. Zob. legenda mapy Districtus Johannisburgensis w zbiorach GStA PK w Berlinie, sygn. F 10319. Na powyższej mapie Józef Naroński zaznaczył obiekty w tuknajnie i Tuchlinie. Na kolejnej, Districtus Reinensis (GStA PK, sygn. F 10329), pochodzącej z 1663 r., zarejestrował: Łuknajno, Tuchlin, Okartowo, Tyrkło oraz Kwik.

$14 \mathrm{H}$. Crome, Kaspar Hennenberger Karte des Alten Preußens, „Alt-Preußen", 5 (2), 1940, s. $27-32$.

15 J. Antoniewicz, Józef Naroński, polski inwentaryzator grodzisk w XVII wieku w Prusach, „Wiadomości Archeologiczne”, 17, 1950, s. 1-24.

16 Die Chronik Wigands von Marburg, w: Scriptores rerum Prussicarum, Hrsg. T. Hirsch, M. Toeppen, E. Strehlke, Bd. 2, Leipzig 1863, s. 596.

17 H. Crome, Verzeichnis der Wehranlagen, „Prussia”, 32 (2), 1939, s. 304.

18 Tamże, 34, 1940, s. 121. Założenie obronne zdaniem Johanna Guisego miało znajdować się na północ od wsi, na krawędzi półwyspu ostro wchodzącego w jezioro Śniardwy. Obecnie na północ od Zdorów nie ma żadnego antropomorficznego obiektu. Prowadzone w okolicy
Kiejstuta w 1378 r. ${ }^{16}$ Grodzisko nad jeziorem Tyrkło pochodzi z wczesnego średniowiecza ${ }^{17}$. W Zdorach nie potwierdzono dotąd grodziska - być może Hennenberger miał zamiar zaznaczyć obiekt na półwyspie Szeroki Ostrów, na którym znajduje się przypuszczalna strażnica z okresu zakonnego ${ }^{18}$. Grodziska w Łuknajnie ${ }^{19}$

badania terenowe Jerzego Głosika nie wykazały istnienia umocnienia na pótnoc od Zdorów, a jedynie na półwyspie Szeroki Ostrów. Por. J. Gtosik, Komunikat o poszukiwaniach archeologicznych w okolicy Jeziora Śniardwy w 1968 r., „Komunikaty Mazursko-Warmińskie” [dalej: KMW], 4 (102), 1968, s. 671-672. Obiekt w Zdorach nie został potwierdzony na mapach Józefa Narońskiego (Districtus Johannisburgensis oraz Disttictus Reinensis), choć kartograf zaznaczył w postaci charakterystycznych kopczyków pozostałe 5 obiektów.

19 H. Crome, Verzeichnis der Wehranlagen, „Prussia”, 33 (1-2), 1939, s. 289. W lipcu 1929 r. obiekt w Łuknajnie wizytował Carl Engel, który zlokalizował go $150 \mathrm{~m}$ od północnego brzegu jeziora Śniardwy. Był to niewielki nasyp 0 wysokości ok. $2,5 \mathrm{~m}$ od strony lądu i $7 \mathrm{~m}$ od strony jeziora, o szerokości podstawy $8 \mathrm{~m}$, znajdujący się na wzgórzu 0 wysokości $121,7 \mathrm{~m}$. Doskonały punkt widokowy na okolicę. W pobliżu odkryto cmentarzysko z wczesnego średniowiecza oraz miecz wikiński. MVF, PM-A 1441/1 Luknainen, Kr. Sensburg. 


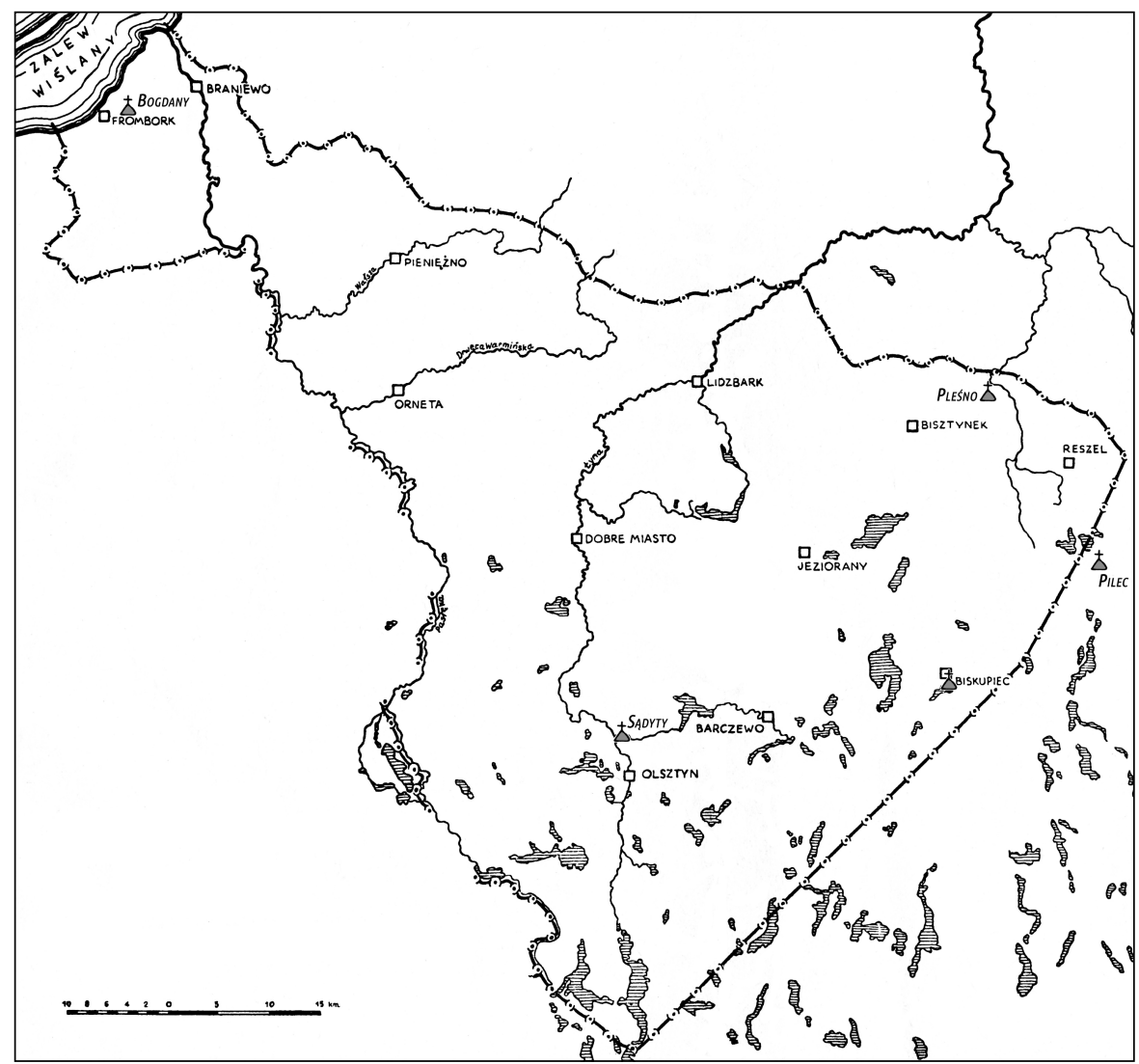

Ryc. 2. Warmia biskupia z grodziskami z mapy Kaspara Hennenbergera, oprac. R. Klimek

i Tuchlinie ${ }^{20}$ zostały w dużym stopniu zniszczone, a ich chronologia nie jest do końca pewna. Obiekt w Nowych Gutach nie jest obecnie znany w literaturze archeologicznej, chociaż we wsi nad jeziorem położone jest dosyć wysokie wzgórze o stromych zboczach, które zostało odnotowane przez Johanna Guisego w latach 1826-1828 podczas inwentaryzacji założeń obronnych na ziemiach pruskich ${ }^{21}$. Jak widać na powyższym przykładzie, typowymi kopczykami Hennen-

20 H. Crome, Verzeichnis der Wehranlagen, „Prussia”, 34, 1940, s. 133. Stanowisko było odnotowane przez Johanna Guisego jako „Schanze Zamedzik", jednak jego szkic nie zachował się do naszych czasów.

21 Tamże, 32 (2), 1939, s. 324; tamże, 34, 1940, s. 106. Hennenberger kopczyk zaznaczył między wsiami Nowe Guty i Kwik. Johann Guise odnotował dwa założenia obronne - w Nowych Gutach i w Kwiku. Niestety jego szkice tych obiektów zaginęty. Na podstawie własnych weryfikacji terenowych oceniam, że na północ od wsi Kwik nie ma obecnie żadnych antropogenicznych form terenowych typowych dla średniowiecznych założeń obronnych. berger oznaczał obiekty o różnej chronologii, od wczesnego średniowiecza począwszy, po czasy krzyżackie. Po drugiej wojnie światowej, w 1948 r. wyżej wzmiankowane stanowiska były inwentaryzowane przez Jerzego Antoniewicza, który do grodzisk zaliczył jedynie obiekty w Tuchlinie i nad jeziorem Tyrkło ${ }^{22}$, natomiast podczas prowadzonych badań w programie Archeologicznego Zdjęcia Polski nie zlokalizowano obiektów w Łuknajnie, Nowych Gutach i Zdorach.

$\mathrm{Na}$ obszarze Warmii biskupiej Kaspar Hennenberger zaznaczył znakiem kopca z krzyżem cztery obiekty: Sądyty (Sanditten) k. Olsztyna, Grzęda-Pleśno (Sturmhofel) w pobliżu jeziora

22 Powyższa dokumentacja znajduje się w zbiorach Archiwum Działu Archeologicznego Muzeum Warmii i Mazur w Olsztynie, w aktach powiatu piskiego. W kolejnych latach Jerzy Antoniewicz podat także w wątpliwość grodzisko w Tuchlinie, mimo że znalazł tam warstwę kulturową z zabytkową ceramiką. 
Sajno (Zain See), Bogdany (Sonnenberg) k. Fromborka, oraz ruiny zamku na terenie miasta Biskupiec (Bischburg). W niniejszym artykule omówię także założenie obronne w Pilcu (Pitlzen), które do $1374 \mathrm{r}$. znajdowało się pod jurysdykcją biskupa warmińskiego ${ }^{23}$.

Zamek w Biskupcu po raz pierwszy pojawił się w źródłach pisanych w 1389 r. ${ }^{24} \mathrm{Na}$ zam-

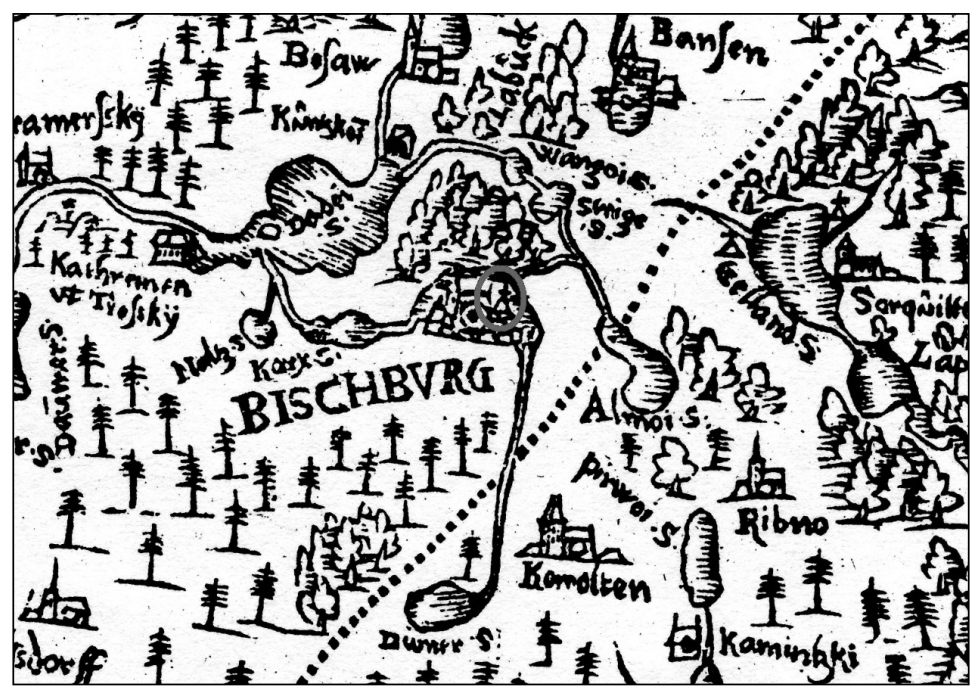

Ryc. 3. Fragment mapy Kaspara Hennenbergera przedstawiający okolicę Biskupca. Po prawej stronie kartograf zaznaczył dwa grodziska - tzw. kopce wartownicze (Stary Gieląd i Mtynik) już spoza obszaru Warmii

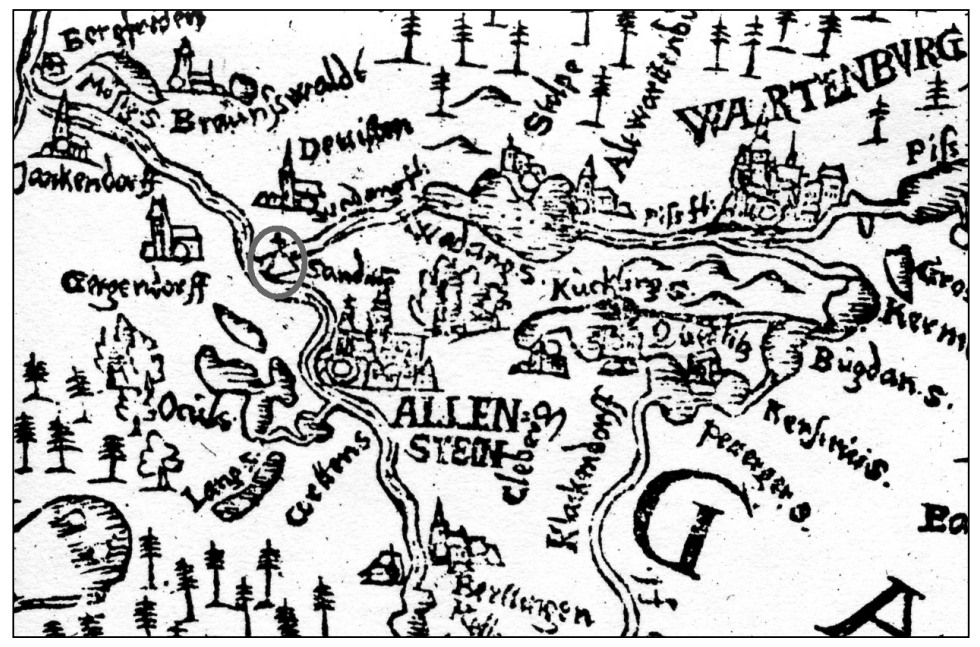

Ryc. 4. Fragment mapy Kaspara Hennenbergera przedstawiający okolice Olsztyna. Na pótnoc od miasta zaznaczono sygnaturą grodzisko Sądyty (Sanditten) ku w Reszlu podpisano dokument nadania dla wsi Bęsia (Bansen). Jednym z punktów granicznych nowej wsi był zamek biskupi - „versus castrum nostrum Bischofsburg". Biskupiec prawa miejskie uzyskał sześć lat później, w dniu 17 października 1395 r., stając się tym samym najmłodszym miastem na terenie Warmii biskupiej. Dokument lokacyjny sporządzony został w miejscowym zamku. Akt ten zawiera kolejną interesującą informację - otóż zezwolono mieszczanom na budowę w obrębie miasta, naprzeciwko obwarowań i palisady, wieży obronnej ${ }^{25}$. Zamek nie przetrwał długo. Zniszczony podczas wojny trzynastoletniej nie podźwignął się już z ruin. W literaturze przedmiotu istnieje hipoteza, jakoby zamek w Biskupcu miał stać na północnym brzegu rzeki Dymer, naprzeciwko kościoła, ale już poza murami miejskimi ${ }^{26}$. W latach 1992-1997 na terenie Biskupca prowadzono prace archeologiczne, podczas których przebadano także obszar, gdzie rzekomo miały znajdować się pozostałości zamku. W świetle przeprowadzonych badań archeolodzy nie znaleźli reliktów takiej budowli, a jedynie pozostałości wczesnonowożytnych pochówków $^{27}$. Wszystko wskazuje zatem, że w tym miejscu nie było żadnych obwarowań, a jedynie stary cmentarz, który znajdował się już poza bramą i murami miasta. Przyjrzyjmy się zatem mapie Hennenbergera. Kartograf zaznaczył kopczyk w północno-wschodniej części miasta, przy południowym brzegu rzeki Dymer i w obrębie obwarowań miejskich. Jest to całkiem inne miejsce od proponowanego dotąd w literaturze. Na podstawie własnych obserwacji terenowych 
oraz mapy Hennenbergera uważam, że zamku należałoby szukać w okolicy ulicy Ogrodowej (dawniej Gartenstraße), między kościołem a rzeką Dymer. Teren ten jest dzisiaj jednak gęsto zabudowany.

Kolejny kopczyk na mapie Prussiae, das ist das Landes zu Preussen zaznaczony został na północ od Olsztyna, w pobliżu ujścia rzeki Wadąg do Łyny. Obok sygnatury widnieje nazwa Sanditten. Niewątpliwie kopczyk wskazuje uroczysko znajdujące się na terenie olsztyńskiego Lasu Miejskiego. Leży ono w zakolu prawego brzegu Łyny, w odległości $800 \mathrm{~m}$ na południe od ujścia rzeki Wadąg. Obiekt ten, ale już bez nazwy, pojawiał się również w niektórych nowożytnych wydaniach map Prus opartych na pracy Hennenbergera: Prussiae vera descriptio Abrahama Orteliusa (1527-1598), Prussia accurate descripta a Gasparo Henneberg Erlichensi autorstwa Johannesa Janssoniusa (występującego również pod nazwiskiem Jan Jansz; 1588-1664) oraz Tabula Prussiae Eximia wydawanych przez Nicolausa Visschera I (1618-1689) i Nicolausa Visschera II $(1649-1702)^{28}$. W latach $1826-1828$

grodzisko zostało zinwentaryzowane przez Johanna Guisego. Plany założenia obronnego podpisał on jako „zamek Sanditten”. Był on położony na południe od ujścia Wadągu do Łyny $^{29}$. Półwysep, na którym znajduje się założenie obronne, sięga $108 \mathrm{~m}$ długości. Prze-

23 W atlasie Eckharda Jägera pt. Prussia-Karten 1542-1810 na pierwszym wydaniu mapy z 1576 r. pojawity się znaki przy miejscowościach: Sturmhofel i Piltzen, natomiast kolejne sygnatury obok miejscowości Bischburg, Sanditten i Sonnenberg znalazły się $w$ drugim wydaniu mapy Hennenbergera, opublikowanej także w Królewcu w 1595 r. E. Jäger, Prussia-Karten 1542-1810, Weißenhorn 1982, s. 56-57.

${ }^{24}$ Codex diplomaticus Warmiensis oder Regesten und Urkunden zur Geschichte Ermlands [dalej: CDW], Hrsg. C.P. Woelky, Bd. 3, Leipzig 1874, nr 238

25 Tamże, nr 307: ,item omnem alium dictam ciuitatem, videlicet de budis et municionibus, que Bercfrede wlgariter nunccupantur, volumus ad ciuitatem et ad eius utilitatem communiter pertinere".

26 B. Koziełto-Poklewski, Kolonizacja. Dominium warmińskie, w: Biskupiec. Z dziejów miasta i powiatu, red. W. Korycka, Olsztyn 1969 s. 65. dzielony jest dwiema krótkimi poprzecznymi fosami. Południowy cypel grodziska, który z trzech stron opływała Łyna, liczył 14 m, a od strony rzeki okalał go wał, który obecnie można zauważyć jedynie od strony wschodniej ${ }^{30}$. Nie widać go ani od strony południowej, ani od zachodniej, co mogło być skutkiem działania erozyjnego Łyny i osunięcia wałów do wody.

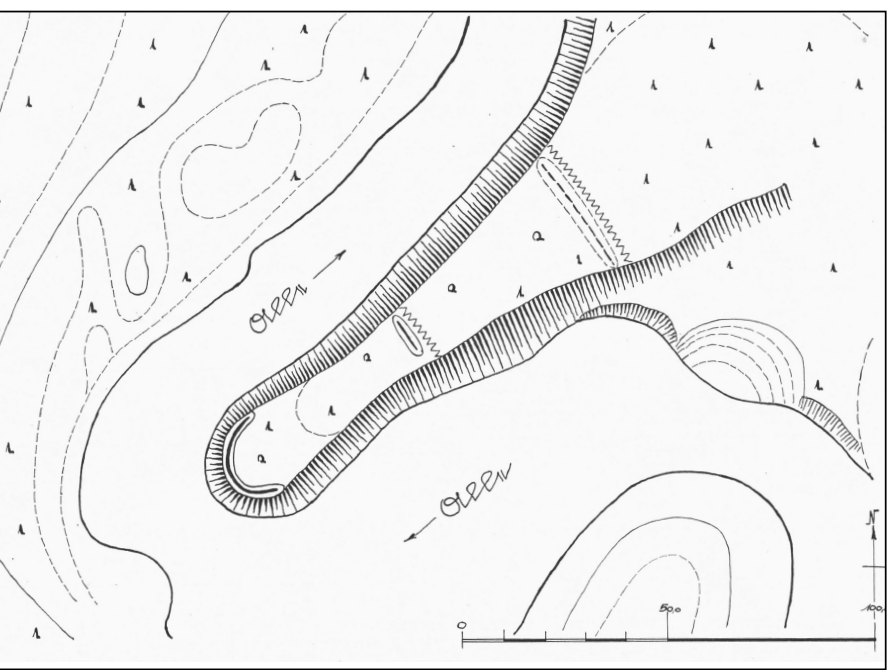

Ryc. 5. L. Fromm, Plan grodziska w Sądytach z lat międzywojennych, zbiory MVF, SB-PK/MVF, IX f3 (Kr. Allenstein)

Na grodzisku widoczne są relikty bramy wjazdowej, która prowadziła do ostatniego punktu oporu, jakim był południowy cypel półwyspu. Nietypowy jest również sam majdan, który usytuowano poniżej bramy wjazdowej. Grodzisko to z całą pewnością można identyfikować ze wsią Sundithen, która jest wymieniona w akcie lokacyjnym Olsztyna. Ta pruska nazwa wywodzi się od słowa sündan, będącego

27 H. Mackiewicz, Wyniki dotychczasowych badań archeologicznych na terenie Starego Miasta Biskupca Reszelskiego, w: Badania archeologiczne starych miast Warmii i Mazur a problem ich rewaloryzacji, red. J. Wysocki, Nidzica 1998, s. 129.

28 Por. przypisy 10 i 14.

29 H. Crome, Verzeichnis der Wehranlagen, „Prussia”, 32 (1), 1938, s. 193. Dokumentacja Johanna Guisego dotycząca grodziska w Lesie Miejskim zaginęta.

30 MVF, PM-A 024/1 Allenstein; MVF, Katalog Burgwallkartei, SMB-PK/ MVF, IX f3 (Kr. Allenstein); G. Białuński, R. Klimek, Początki Olsztyna, Olsztyn 2013, s. 11-14. 
biernikiem liczby pojedynczej rzeczownika kara. Sundithen (Sundyty), jako nazwa pochodząca z języka pruskiego, mogłaby oznaczać miejsce sądu - religijnego lub świeckiego ${ }^{31}$, i wiele fragmentów wczesnośredniowiecznej ceramiki ${ }^{33}$. Niewątpliwie do dokładnej weryfikacji tego miejsca skłonił mnie przede wszystkim znak na mapie Hennenbergera. Uważa-

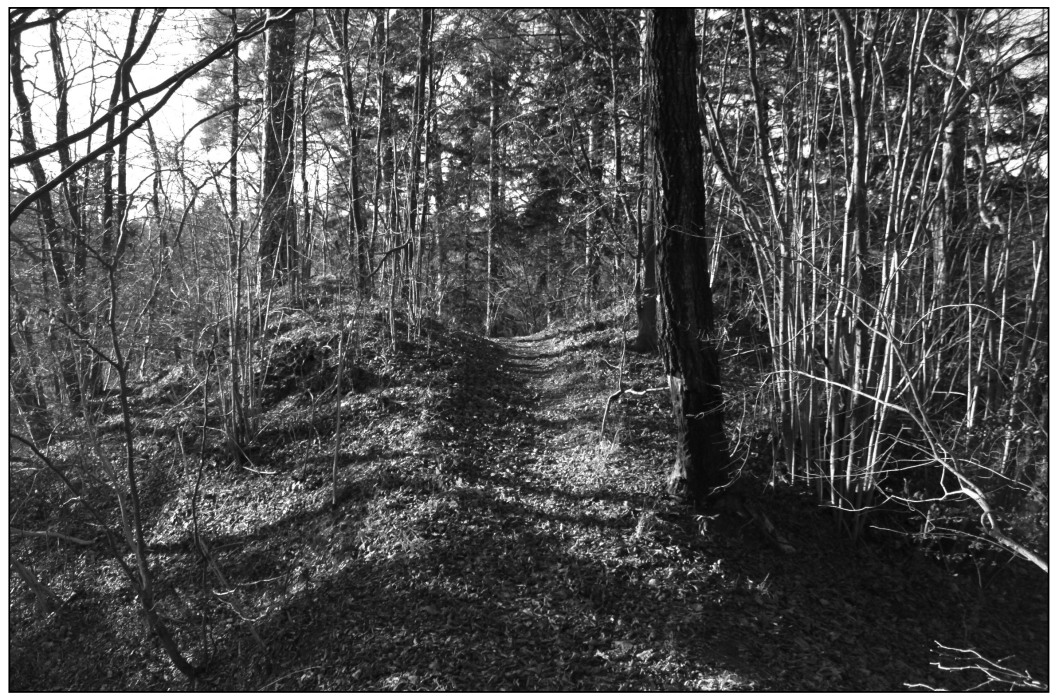

Fot. 1. Widok na relikty bramy wjazdowej grodziska Sądyty (fot. R. Klimek)

raczej połączonego, gdyż o innym nie mogło być wówczas mowy. Grodzisko było znane w literaturze niemieckiej. Po drugiej wojnie światowej zostało negatywnie zweryfikowane przez archeologów podczas prowadzonych badań powierzchniowych w ramach Archeologicznego Zdjęcia Polski (dalej: AZP) ${ }^{32}$. W latach 2004-2005 dwukrotnie zgłaszałem grodzisko Wojewódzkiemu Konserwatorowi Zabytków (dalej: WKZ) w Olsztynie, ale bez efektu - nie podjęto wówczas żadnych działań, sugerując się wcześniejszymi badaniami AZP, w których nie stwierdzono w tym miejscu śladów wczesnośredniowiecznego założenia obronnego. W kwietniu 2006 r. obok grodziska odkryłem osadę przygrodową. Podczas prowadzonych tam jesienią 2006 r. prac wykopaliskowych znaleziono wiele cennych zabytków: dirhamy, groty strzał, przedmioty codziennego użytku

31 V. Mažiulis, Prūsu kalbos. Etimologijos žodynas, t. 4: R-Z, Vilnius 1997, s. 167-168.

32 Dokumentacja AZP nr 23-61, numer stanowiska 46 - obiekt został ujęty w dokumentacji dopiero w $2006 \mathrm{r}$. łem, że uroczysko Sanditten nie zostało przez tego wybitnego kartografa zaznaczone w tym miejscu przypadkiem.

W 1278 r. pojawia się wzmianka o zamku w Bogdanach (niem. Sonnenberg) - Castrum Sunnemberg - nad rzeką Baudą, położonym niedaleko Fromborka ${ }^{34}$. Dwie następne informacje pochodzą z 1304 r. ${ }^{35} \mathrm{~W}$ kolejnych latach warownia prawdopodobnie straciła na znaczeniu, ponieważ nie jest określana w źródłach jako castrum lecz mons ${ }^{36}$. Wówczas zamieszkiwał ją Henryk - prepozyt kapituły warmińskiej. Obiekt ten został zaznaczony na mapie Kaspara Hennenbergera jako grodzisko

\footnotetext{
33 M. Hoffmann, A. Koperkiewicz, Sprawozdanie z badań archeologicznych na stanowisku LXXIX i CIV, AZP 23-61/46, Olsztyn - Las Miejski, Olsztyn 2006, dokumentacja ze zbiorów WKZ w Olsztynie.

34 CDW, Bd. 1, nr 54. Nazwę sunne można wiązać z pruskim saule, oznaczającym słońce. Por. V. Mažiulis, Prūsų kalbos, s. 72-75. Odpowiednik niemiecki Sonnenberg oznaczał 'słoneczne wzgórze'.

35 CDW, Bd. 1, nr 126, 130.

36 Tamże, nr 150 - „in monte Sonnenberg” (1309); tamże, nr 195 „monte Sunnenberch” (1314).
}

\section{Studia Geohistorica • Nr 03. 2015}


położone na prawym brzegu rzeki Bauda ${ }^{37}$. Nie ma wątpliwości, że autor zaznaczył relikty warowni w Bogdanach. W pracy Erclerung der preussischen grössern Landtaffel oder Mappen napisał, że znajdowała się tam siedziba Zompny z rodu Nartzenów ${ }^{38}$. W latach $1826-1828$ grodzisko inwentaryzował Johann Guise, który w swoich notatkach zaznaczył, że jest to

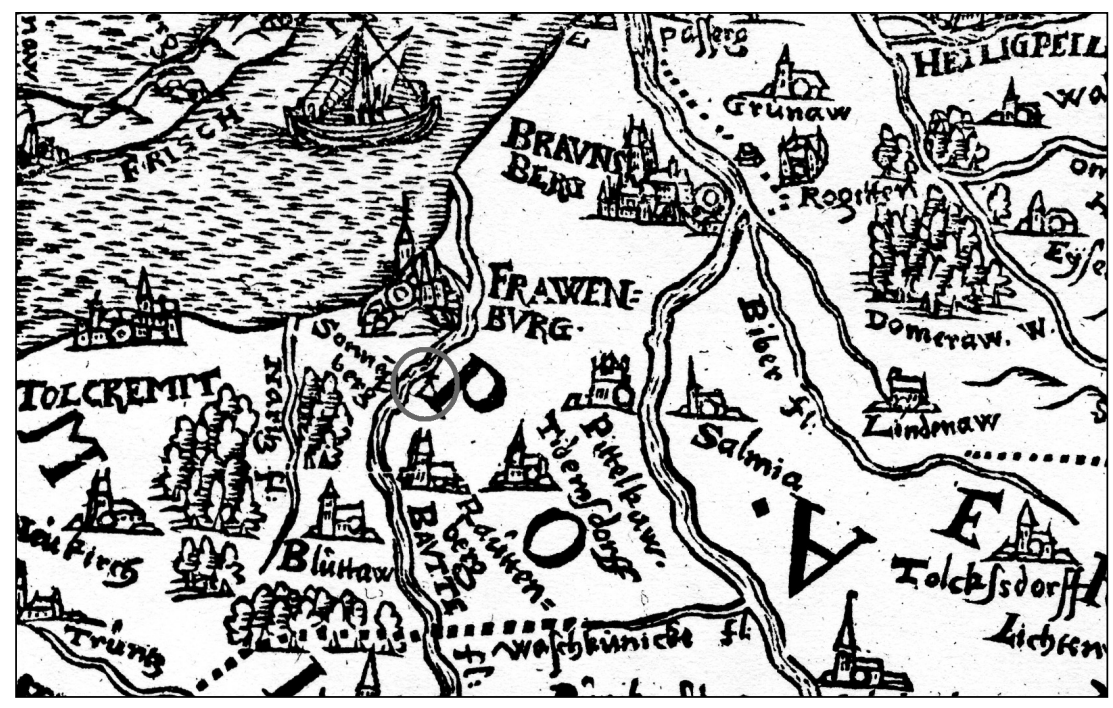

Ryc. 6. Fragment mapy Kaspara Hennenbergera przedstawiający okolicę Fromborka. Widać Frombork od strony południowej oraz grodzisko w Bogdanach (Sonnenberg)

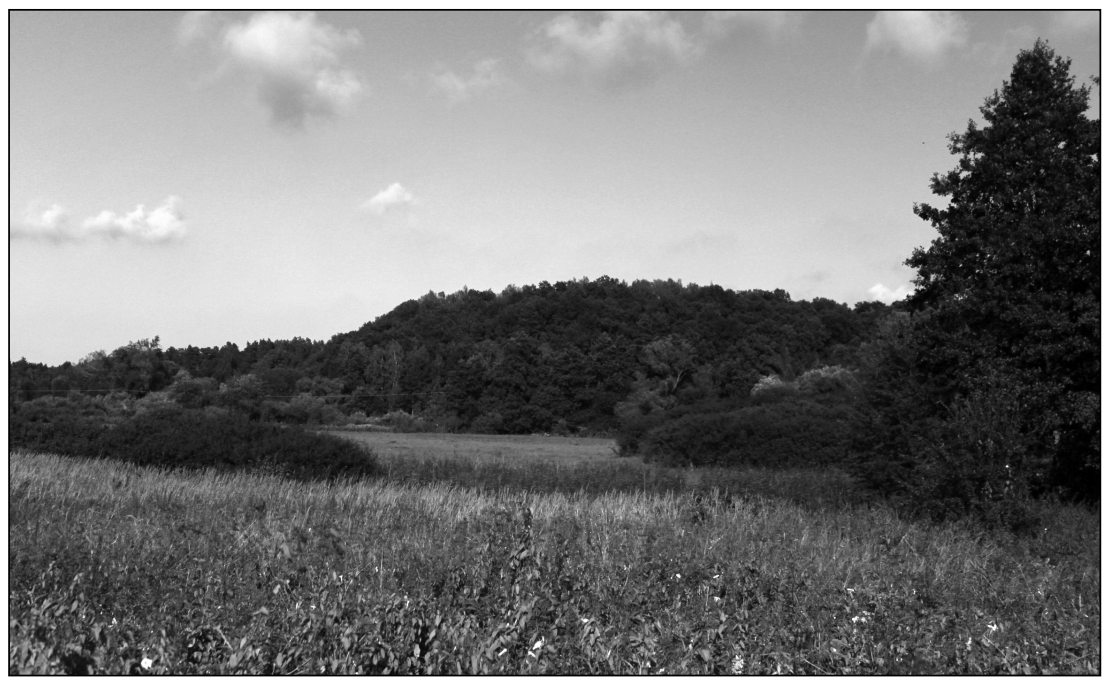

Fot. 2. Widok na grodzisko w Bogdanach od strony południowo-zachodniej (fot. R. Klimek)

37 R. Klimek, Zaginione zamki i strażnice poświadczone w źródłach z pierwszej połowy XIV wieku z obszaru Warmii biskupiej oraz propozycje ustalenia ich lokalizacji, w: Archaeologica Hereditas. Grodziska
Warmii i Mazur. Stan wiedzy i perspektywy badawcze, red. Z. Kobyliński, Warszawa-Zielona Góra 2013, s. 205-207.

38 C. Hennenberger, Erklarung, s. 436: „Wohnsitz der Zompna vom Geschlechte der Nartzen". 
zamek Zompny nad Baudą przy Sonnenber$\mathrm{gu}^{39}$. W dziewiętnastowiecznych sprawozdaniach naukowych górę określano jako pogańskie miejsce ofiarne ${ }^{40}$. Na niemieckich mapach sztabowych grodzisko figuruje jako Pogańska Góra (Heiden-Berg) ${ }^{41}$. Badania archeologiczne wykazały, że powyższe założenie obronne było użytkowane w VII-VIII oraz XIII-XIV w. ${ }^{42}$ Niewątpliwie rozwój pobliskiego Fromborka sprawił, że warownia w Bogdanach utraciła w XIV w. na znaczeniu i ostatecznie całkowicie upadła.

Kolejny kopczyk na terenie Warmii biskupiej Kaspar Hennenberger zaznaczył na zachodnim brzegu jeziora Sajno, na zachód od Reszla. Znak ten był powielany na nowożytnych przeróbkach jego map ${ }^{43}$. Miejsce owo położone jest w pobliżu wsi Pleśno (Plößen)

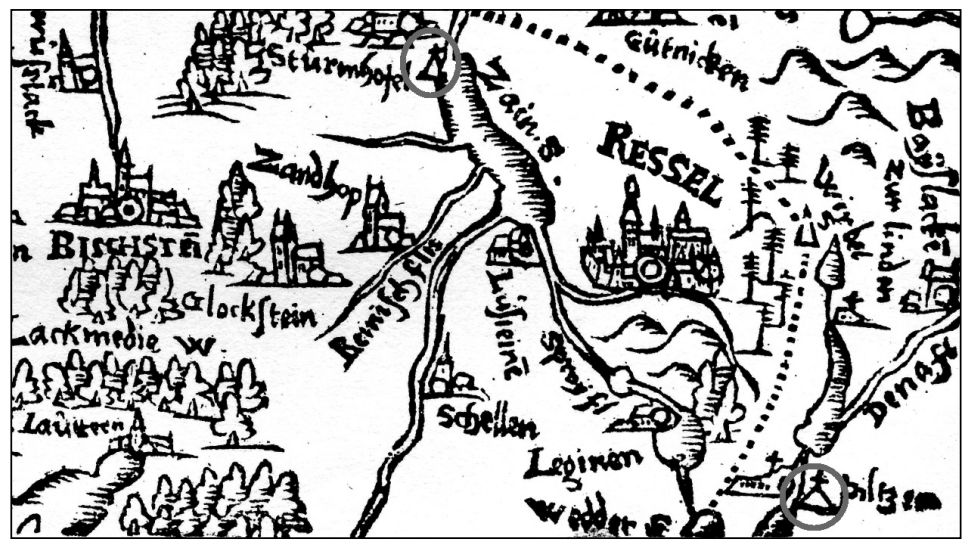

Ryc. 7. Fragment mapy Kaspara Hennenbergera przedstawiający okolice Reszla. Na mapce przedstawione są sygnatury przy obiektach w Pilcu (Piltzen) i Grzędzie-Pleśno (Sturmhofel). Warto zwrócić uwagę na wizerunki kościołów w Uniszewie (Glockstein) i Sątopach (Santhopen), są bowiem identyczne ze wspótczesnymi

Ryc. 8. Fragment mapy Abrahama Orteliusa „Prussiae vera descriptio" z obiektami w Pilcu iPleśnie

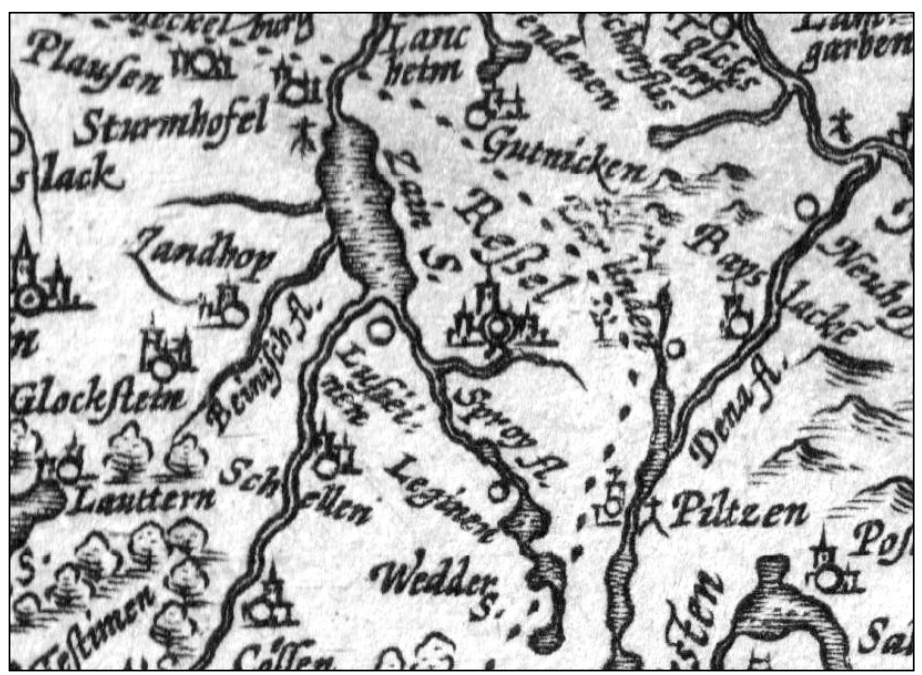

39 MVF, Guise Zettel, 178a (Grundriss und Ansicht des Schlossberges bei Althof; Zompnas Schloß an der Baude bei Sonnenburg. Zompna, der Narzen Königin).

40 MVF, PM-A 787/1 (Sonnenberg, Kr. Braunsberg).

41 Meßtischblatt, Nr 1684, Braunsberg (West.) 1:25 000, [b.m.w.].

42 R. Odoj, Sprawozdanie z prac wykopaliskowych na grodzisku Bogdany koto Fromborka prowadzonych w 1970 r., KMW, 4 (110), 1970 s. 659-666; M. Jagodziński, Archeologiczne ślady osadnictwa między Wistą a Pasłęką we wczesnym średniowieczu. Katalog stanowisk, Warszawa 1997, s. 23-24; D. Gazda, Między grodem a zamkiem wieloczłonowe obiekty warowne prusko-krzyżackie na południe od Zalewu Wiślanego, w: Archaeologica Hereditas, s. 125-134.

43 Oprócz wzmiankowanych map Orteliusa, Meriana, Janssoniusa i Visschera sygnatury znajdowały się także na mapie Christophera Hart- 
i było wzmiankowane w latach 20. XIX w. W sprawozdaniu Landrata z Reszla z 5 maja 1825 r. podano, że na północny zachód od Pleśna położone było stanowisko obronne zwane Schwedenschanze. W kolejnych latach okolice zachodniego brzegu tutejszego jeziora weryfikował terenowo Guise, który odnotował tam trzy umocnienia. Pierwsze z nich leżało na lewym, zachodnim brzegu Sajny. Drugie znajdowało się w jego pobliżu, a trzecie - na zachód od wspomnianych, czyli na południe od drogi w kierunku wsi Grzędy ${ }^{44}$. W okresie międzywojennym okolice wizytował dyrektor Prussia Muzeum w Królewcu dr Wilhelm Gaerte. Nie znalazł on żadnych śladów umocnień, ale zauważył, że mieszkańcy Pleśna nazywają pewne miejsce Wallberg. Było ono położone na południe od drogi Grzęda-Pleśno, koło mostu i na zachodnim brzegu rzeki Sajna. Właścicielem pola był zaś niejaki Krüger. Podczas wizytacji terenowej tego miejsca stwierdzilem, że omawiany obszar został całkowicie wyrównany. Należy zwrócić uwage na fakt, że okolice Pleśna i Grzędy w poł. XIX w. bardzo się zmieniły ${ }^{45}$. Jezioro Sajno zostało osuszone, zaś wzdłuż jego zachodniego i wschodniego brzegu wybudowano kanały odwaniające. W latach 1871-1873 przez wieś Pleśno przeprowadzono linię kolejową Olsztyn-Gubin, co moim zdaniem w znacznym stopniu przyczyniło się do zniszczenia pobliskich stanowisk obronnych ${ }^{46}$.

Ostatnim z omawianych obiektów zaznaczonych na mapie Hennenbergera jest zameczek w Pilcu. Miejscowość ostatecznie znalazła się po stronie zakonu krzyżackiego, ale do czasu rozstrzygnięcia sporu granicznego

knocha (1644-1687) Prussia accurate descripta a Gasparo Henneberg Erlichensi oraz Petera Schenka (1660-1718) Regni Prussici Accuratissima Delineatio (Amsterdam ok. 1713).

44 MVF, Guise Zettel PM-IXh: 104b.

45 H. Crome, Verzeichnis der Wehranlagen, „Prussia”, 32 (2), 1939, s. 322

46 A. Piątkowski, Kolej wschodnia w latach 1842-1880. Z dziejów transportu kolejowego na Pomorzu Wschodnim , Olsztyn 1996, s. 186. w 1374 r. pozostawała pod jurysdykcją biskupa warmińskiego ${ }^{47}$. Według dokumentu z 24 czerwca 1369 r. granica dominium warmińskiego przebiegała blisko zamku w Pilcu: ,ad granicam positam retro Resel iuxta castrum Piltcz". Następnie dokument szczegółowo określa jej przebieg: „Item ab alia parte retro Resel a granica posita circa Piltcz per Seysten ad lacum Kerwoyke et fluuium qui ab eo fluit, et habet in longitudine viij miliaria" - granica przebiegała od Reszla obok Pilca przez Szestno do Jeziora Kierwik i rzeki, która z niego wypływa. Łączna długość linii granicznej wy-

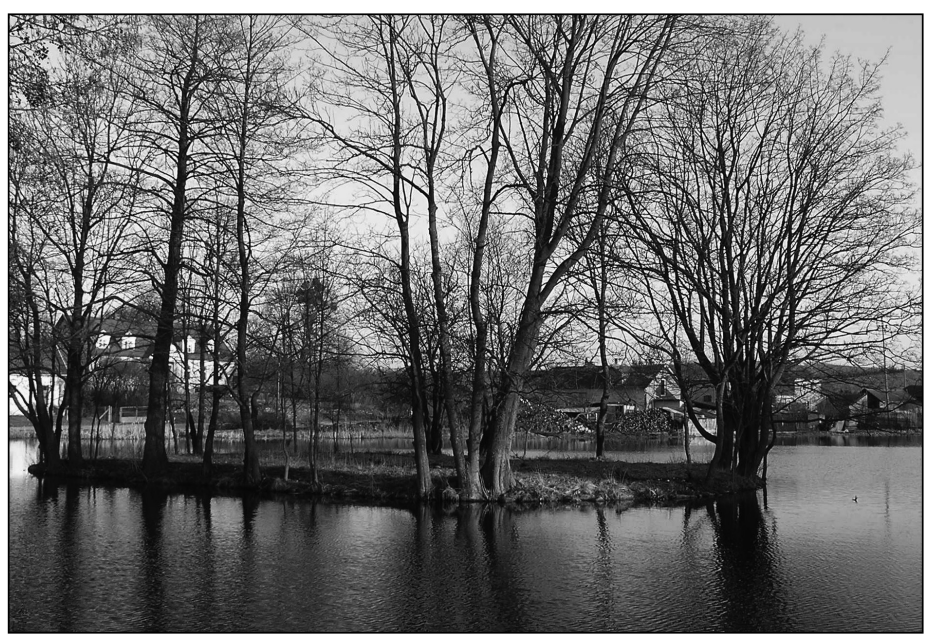

Fot. 3. Wyspa na Stawie Młyńskim w Pilcu - przypuszczalne relikty średniowiecznej strażnicy (fot. R. Klimek) nosiła $8 \mathrm{mil}^{48}$. W późniejszych latach strażnica w Pilcu nie występowała w źródłach. Wspominał o niej dopiero Hennenberger w 1595 r., jednak nie podał dokładnego położenia ${ }^{49} . \mathrm{Na}$ mapie znak umieszczony jest po lewej stronie przepływającej przez wieś rzeki Dajna. Podobnie - za Hennenbergerem - na swoich mapach stanowisko to zaznaczyli Janssonius

\footnotetext{
47 CDW, Bd. 2, nr 497. Przebieg granicy na tym odcinku ustalono na linii: las Krakocin (silua Krakotin) - Kurki, pozostawiając Pilec po stronie zakonu. 48 Scriptores rerum Warmiensium oder Quellenschriften zur Geschichte Ermlands, Bd. 1, Hrsg. J.M. Saage, C.P. Woelky, Braunsberg 1866, s. 30-31.

49 C. Hennenberger, Erklarung, s. 349: „Piltzen - ein Schlos gehabt/und dem Bischoff von Ermlande die Grentze alda".
} 
oraz Visscher. W nieco innym miejscu relikty strażnicy widział Józef Naroński - kartograf w służbie księcia pruskiego. Na powstałej w latach 60. XVII w. mapie Districtus Rastemborgensis sygnaturę $\mathrm{w}$ postaci kopczyka $\mathrm{z}$ krzyżem Naroński zaznaczył na wyspie znajdującej się w północnej części Stawu Młyńskiego ${ }^{50}$. W latach 1826-1828 Pilec odwiedził Guise i także on odnotował, że relikty zameczku miały znajdować się na wyspie położonej na Stawie Młyńskim $^{51}$. Wspomniana wysepka zachowała się do obecnych czasów, jednak jak dotąd nie przeprowadzono na niej badań archeologicznych. Jest niewielka, więc można przypuszczać, że strażnica, która na niej stała, nie odgrywała ważnej roli militarnej, co najwyżej obserwacyjną. Podczas prowadzonych badań AZP w ogóle nie uwzględniono wyspy, natomiast przypuszczalne położenie zameczku ustalono ok. $1 \mathrm{~km}$ na północ od wsi ${ }^{52}$.

Analizując na mapie Hennenbergera położenie kopców na obszarze dominium warmińskiego, warto zaznaczyć, że mają one swoje potwierdzenie bądź to w terenie, jak grodziska w Bogdanach i olsztyńskim Lesie Miejskim, bądźwźródłach pisanych, jakzamekw Biskupcu i strażnica w Pilcu. Założenie obronne w pobliżu jeziora Sajno nie dotrwało do naszych czasów. Weryfikacje terenowe, szczególnie te z 1. poł. XIX w., pozwalają jednak domniemywać, że takie istniało. Wybudowanie kanałów odwadniających oraz nasypów kolejowych prawdopodobnie spowodowało jego niwelację. Cały czas otwarta pozostaje sprawa położenia zamku w Biskupcu. Dotąd w literaturze przedmiotu nie zauważono, że Hennenberger zaznaczył ruiny tego założenia obronnego w północno-wschodniej części miasta, nad lewym brzegiem rzeki Dymer. Nie jest wykluczone, że w przyszłości może być to wskazówka do odnalezienia reliktów jego fundamentów na terenie biskupieckiego Starego Miasta. Sygnatura zaznaczona przez kartografa na północ od Olsztyna kilka lat temu stała się dla mnie poważnym bodźcem do dokładnej weryfikacji terenowej Lasu Miejskiego na prawym brzegu Łyny. W efekcie oprócz wspaniałego grodziska, które wcześniej było negatywnie zweryfikowane przez miejscowych archeologów, odkryłem nieznaną dotąd pokaźną wczesnośredniowieczną osadę przygrodową ${ }^{53}$. Do analizy pozostaje jeszcze blisko 50 sygnatur z mapy Hennenbergera. Wydaje się, że po przeprowadzeniu dokładnej kwerendy źródłowej i terenowej dowiemy się, iż niektóre z nich kryją jeszcze niejedną zapomnianą zagadkę historyczną.
50 J. Districtus Rastemborgensis, GStA PK, XX, HA, Karte F 10.328. J. Szeliga, Rękopiśmienne mapy Prus Książęcych Józefa Naronowicza-Narońskiego z drugiej połowy XVII wieku, Warszawa 1997, mapa nr 7.

51 MVF, Guise Zettel 118a (Grundriss und Ansicht des Burgwalls von Pilz); H. Crome, Verzeichnis der Wehranlagen, Bd. 34, 1940, s. 105.

52 Dokumentacja AZP nr 19-68. Prowadzący badania Jacek Wysocki za grodzisko będące pozostałością zamku w Pilcu uznał wzgórze 0 wysokości 119 m n.p.m., które położone jest na północ od wsi, po zachodniej stronie rzeki. Do propozycji archeologa odnoszę się jednak sceptycznie. Weryfikowałem to miejsce i moim zdaniem istnieją nikłe przesłanki do tego, aby właśnie tam znajdowała się wzmiankowana w źródłach strażnica. W swoich badaniach autor w ogóle nie odniósł się do literatury i źródeł kartograficznych. Na tym samym obszarze AZP popełnił kilka błędów, m.in. w ogóle nie odnalazł wałów podłużnych, które występują w okolicy Świętej Lipki.

53 Przypuszczenia co do istnienia w tym miejscu osady związanej z wsią Sądyty (Sanditten) miał Leonard Fromm, który zaznaczył ją na mapie archeologicznej powiatu olsztyńskiego. L. Fromm, W. Steffel, Kreiskarte Stadt- und Landkreis Allenstein, skala 1:100 000, Allenstein 1941. 


\section{Bibliografia}

Źródła archiwalne i niepublikowane

Archiwum Warmińsko-Mazurskiego Wojewódzkiego Konserwatora Zabytków w Olsztynie

Dokumentacja AZP obszarów: 19-68, 23-61.

Hoffmann M., Koperkiewicz A., Sprawozdanie $z$ badan archeologicznych na stanowisku LXXIX i CIV, AZP 23-61/46, Olsztyn - Las Miejski, Olsztyn 2006.

Dział Historyczny Muzeum Warmii i Mazur w Olsztynie

Hennenberger C., Prussia das ist des Landes zu Preussen, Königsberg 1629, wyd. 4, sygn. DH 5236.

Geheimes Staatsarchiv Preussischer Kulturbesitz, XX, HA, Berlin-Dahlem (GStA PK)

Naronski J., Districtus Johannisburgensis, sygn. F 10.319 .

Naronski J., Districtus Sestensis, 1663, sygn. F 10.330 .

Naronski J., Districtus Rastemborgensis, sygn. F 10.328 .

\section{Źródła wydane drukiem}

Codex diplomaticus Warmiensis oder Regesten und Urkunden zur Geschichte Ermlands, Hrsg. C.P. Woelky, J.M. Saage, Bd. 1, Mainz 1860.

Codex diplomaticus Warmiensis oder Regesten und Urkunden zur Geschichte Ermlands, Hrsg. C.P. Woelky, J.M. Saage, Bd. 2, Mainz 1864.

Codex diplomaticus Warmiensis oder Regesten und Urkunden zur Geschichte Ermlands, Hrsg. C.P. Woelky, Bd. 3, Leipzig 1874.

Die Chronik Wigands von Marburg, w: Scriptores rerum Prussicarum, Hrsg. T. Hirsch, M. Töppen, E. Strehlke, Bd. 2, Leipzig 1863.

\section{Źródła kartograficzne}

Caspar Hennenberger's Grosse Landtafel von Preussen in 9 Blättern (Erste Ausgabe vom Jahre 1576), Königsberg 1863, skala 1:400 000.

Naronski J., Disrtictus Reinensis, 1663, sygn. 10.329.

Museum für Vor- und Frühgeschichte Archiv w Berlinie (MVF)

PM-A 024/1 (Allenstein); PM-A 787/1 (Sonnenberg, Kr. Braunberg); PM-A 1045/1 (Pülz, Kr. Rastenburg);

Katalog Burgwallkartei SMB-PK/MVF, IX f3 (Kr. Allenstein): Allenstein.

Guise Zettel PM-IXh:

104b (Ansicht von Plössen; Ansicht von Rössel gegenosten; Grundriss einer Schanze (?) bei Plössen; Grundriss der Schanze bei „Grünhof am Zain-See”);

118a (Grundriss und Ansicht des Burgwalls (?) von „Pilz” [Pülz]);

178a (Grundriss und Ansicht des Schlossberges bei Althof „Zompnas Schloß an der Baude bei Sonnenburg. Zompna, der Narzen Königin").

Hartknoch Ch., Alt- und neues Preussen, oder preussischer Historien zwei Theile, Frankfurt-Leipzig 1684.

Hennenberger C., Erclerung der preussischen grössern Landtaffel oder Mappen, Königsberg 1595.

Merian M., Topographia Elektoratus, Brandenburgici et Ducatus Pomeraniae (Faksimile der Erstausgabe von 1652), Kassel-Basel 1965.

Scriptores rerum Warmiensium oder Quellenschriften zur Geschichte Ermlands, Bd. 1, Hrsg. J.M. Saage, C.P. Woelky, Braunsberg 1866.

Fromm L., Steffel W., Kreiskarte Stadt- und Landkreis Allenstein 1:100 000, Allenstein 1941. 
Hartknoch Ch., Prussia accurate descripta a $G a-$ sparo Henneberg Erlichensi, Leipzig 1684.

Hennenberger C., Kurze und warhafftige Beschreibung des Landes zu Preussen, 1584.

Hennenberger C., Prussiae, das ist des Landes zu Preussen, welches das herrichste Theil ist Sarmathiae Europae eigentliche und warhafftige Beschreibung, Königsberg 1576, skala ok. 1:370 000 .

Homman J.B., Regnum Borussiae, Norimbergae 1710, skala ok. 1:750 000 .

Janssonius J., Prussia accurate descripta a $G a-$ sparo Henneberg Erlichensi, Amsterdam 1647-1658, skala ok. 1:750 000.

Mercator G., Prussia, w: Atlas sive cosmographicae, Duisburg 1595, skala ok. 1:750 000.

Literatura przedmiotu

Alexandrowicz S., Kartografia Wielkiego Księstwa Litewskiego od XV do potowy XVIII wie$k u$, Warszawa 2012.

Antoniewicz J., Józef Naroński, polski inwentaryzator grodzisk w XVII wieku w Prusach, ,Wiadomości Archeologiczne", 17, 1950, s. 1-24.

Białuński G., Klimek R., Początki Olsztyna. Przewodnik archeologiczny, Olsztyn 2013.

Biskupiec. $Z$ dziejów miasta i powiatu, red. W. Korycka, Olsztyn 1969.

Crome H., Verzeichnis der Wehranlagen Ostpreußens, „Prussia”, 32 (1), 1938, s. 173-209.

Crome H., Verzeichnis der Wehranlagen Ostpreußens, „Prussia”, 32 (2), 1939, s. 297-324.

Crome H., Verzeichnis der Wehranlagen Ostpreußens, „Prussia”, 33 (1-2), 1939, s. 263-289.

Crome H., Verzeichnis der Wehranlagen Ostpreußens, „Prussia”, 34, 1940, s. 83-155.

Crome H., Kaspar Hennenberger Karte des Alten Preußene, „Alt-Preußen”, 5 (2), 1940, s. 27-32.

Gazda D., Między grodem a zamkiem - wielocztonowe obiekty warowne prusko-krzyżackie na potudnie od Zalewu Wiślanego, w: Archaeologica Hereditas. Grodziska Warmii i Mazur. Stan wiedzy i perspektywy badawcze, red. Z. Kobyliński, Warszawa-Zielona Góra 2013, s. 125-134.

Głosik J., Komunikat o poszukiwaniach archeologicznych w okolicy Jeziora Śniardwy
Meßtischblatt, $\mathrm{Nr}$ 1684, Braunsberg (West.) 1:25 000, [b.m.w.] 1937.

Ortelius A., Prussiae vera descriptio, w: Theatrum Orbis Terrarum, Antwerpia 1584, skala ok. 1:750 000.

Schenk P., Regni Prussici Accuratissima Delineatio, Amsterdam [ok. 1713], skala ok. 1:750 000 .

Seutter M., Borussia Regnum, Augsburg 1720, skala ok. 1:750 000.

Vaugondy G.R., La Prusse divisée en Prusse Royale, et Prusse Ducale, Paris 1751, skala ok. 1:750 000.

Visscher N., Tabula Prussiae Eximia, Amsterdam 1630-1681, skala ok. 1:750 000.

w 1968 r., „Komunikaty Mazursko-Warmińskie", 4 (102), 1968, s. 671-672.

Grabowski P., Obraz terytorium Prus Wschodnich w kartografii XV-XIX wieku, w: Ziemie dawnych Prus Wschodnich w kartografii, red. P. Grabowski, J. Ostrowski, Olsztyn 1997, s. $19-48$.

Jäger E., Prussia-Karten 1542-1810, Weißenhorn 1982.

Jagodziński M., Archeologiczne ślady osadnictwa między Wista a Pastękq we wczesnym sredniowieczu. Katalog stanowisk, Warszawa 1997.

Klimek R., Zaginione zamki i strażnice poświadczone w źródtach z I potowy XIV wieku na Warmii biskupiej oraz propozycje ustalenia ich lokalizacji, w: Archaeologica Hereditas. Grodziska Warmii i Mazur. Stan wiedzy i perspektywy badawcze, red. Z. Kobyliński, Warszawa-Zielona Góra 2013, s. 205-224.

Koziełło-Poklewski B., Kolonizacja. Dominium warminiskie, w: Biskupiec. $Z$ dziejów miasta i powiatu, red. W. Korycka, Olsztyn 1969, s. 48-60.

Mackiewicz H., Wyniki dotychczasowych badan archeologicznych na terenie Starego Miasta Biskupca Reszelskiego, w: Badania archeologiczne starych miast Warmii i Mazur a problem ich rewaloryzacji, red. J. Wysocki, Nidzica 1998, s. 127-131. 
Mažiulis V., Prüsų kalbos etimologijos žodynas, t. 4, Vilnius 1997.

Odoj R., Sprawozdanie z prac wykopaliskowych na grodzisku Bogdany koto Fromborka prowadzonych w 1970 r., KMW, 4 (110), 1970, s. 659-666.

Oracki T., Stownik biograficzny Warmii, Prus Ksiażęcych i Ziemi Malborskiej od potowy XV do konca XVIII wieku, t. 1: A-K, Olsztyn 1984.

Piątkowski A., Kolej wschodnia w latach 1842 1880. Z dziejów transportu kolejowego na Pomorzu Wschodnim, Olsztyn 1996.
Szeliga J., Dziatalnośc kartograficzna Samuela i Jana Wtadystawa Suchodolców w Prusach w XVII i XVIII wieku, Warszawa 2004.

Szeliga J., Rękopismienne mapy Prus Ksiażęcych Józefa Naronowicza-Narońskiego z drugiej potowy XVII wieku, Warszawa 1997.

Szeliga J., Rozwój kartografii Wybrzeża Gdańskiego do roku 1772, Wrocław-WarszawaKraków-Gdańsk-Łódź 1982.

\section{The Ruins of Castles and Strongholds in the Area of Warmia Bishopric on the Map by Kaspar Hennenberger (1576)}

\section{Summary}

In 1576, in Königsberg the first detailed map of the Duchy of Prussia by Kaspar Hennenberger (1529-1600) was published - Prussiae, das ist das Landes zu Preussen welche herrliste Theil ist Sarmathiae Europeae eigentliche und warhafftige Beschreibung. It played a prominent role in the history of cartography of that area and as long as until the middle of the $18^{\text {th }}$ century it provided the basis of the maps of Prussia published in the west of Europe. Hennenberger made his map mainly basing on his own measurements and materials collected in the years 1569-1576, during a 7-year-long journey around the country. On the basis of the measurements, the map's scale is 1:368 000. Numerous editions and modifications indicate the value of the map and a need for it. It was as early as in 1595 that it had the second edition supplemented with a broad historical description. The subsequent editions appeared in 1627, 1629, 1638, 1639, 1655 and 1679. The picture of the settlement network is characterized by the greatest variety of presentations. An important iconographic symbol in Hennernberger's maps, which is however frequently neglected in the literature of the subject, are the marks in the shape of mounds with a cross, in the map key described as - Ein Berg da vor alters ein Schloss drauf gewesen - which means a hill where a castle (a hillfort) was situated. In the map Prussiae, das ist das Landes zu Preussen Hennenberger placed 55 symbols signifying this type of structures. He placed most of them, namely 6 , in the area of Śniardwy lake and 5 in the vicinity of Insterburg. In the territory of the Bishopric of Warmia Hennenberger provided symbols for four constructions: Sądyty (Sanditten) near Olsztyn, Bogdany (Sonnenberg) near Frombork, GrzędaPleśno - (Sturmhofel) near lake Sajno (Zain See) and the ruins of a castle in the area of the town of Biskupiec (Bischburg). The present paper also discussed the defensive constructions in Pilec (Pitlzen), which was under the jurisdiction of the bishop of Warmia till 1374.

The analysis of the placement of symbols in Hennenberger's maps in the area of the Warmia dominium points out that they are confirmed either in the area, e.g. hillforts in Bogdany and in the Citry Forest of Olsztyn, or in written sources such as the castle in Biskupiec and a watchtower in Pilec. The defensive constructions near lake Sajno have not survived till now. However, field verifications, especially those from the first half of the $19^{\text {th }} \mathrm{c}$. 
point out that they existed. The matter of the localization of the castle in Biskupiec still remains open. So far, it has not been noticed in the literature of the subject that Hennenberger marked the ruins of that defensive construction in the north-eastern part of the town, on the left bank of the river Dymer. Nearly 50 more symbols from Hennenberger's map remain to be analyzed. It seems that after a thorough research of the sources and in the field we will find out that some of them hide many a forgotten historical mystery.

Słowa kluczowe: Kaspar Hennenberger, Warmia, grodziska, ruiny zamków

Keyw ords: Kaspar Hennenberger, Warmia, strongholds, ruins of castles

mgr Robert Klimek (Olsztyn) - z wykształcenia politolog, z zamiłowania badacz kultury materialnej Prusów. Prowadzi badania interdyscyplinarne gtównie na temat krajobrazu kulturowego pozostałości Prusów (grodziska, wały podłużne, obiekty kultu). Pisze doktorat o szlakach komunikacyjnych Warmii biskupiej w latach 1243-1466

(e-mail: robertusklimek@wp.pl) 